\title{
Core Business Process Management and Company Performance
}

\author{
DUŠAN GOŠNIK \\ University of Primorska, Slovenia \\ dusan.gosnik@fm-kp.si
}

This article deals with the management of business processes activities with an emphasis on core processes as well as their influence on company performance. Article focuses on how core process management, which encompasses the activities of planning, organizing, leading, and controlling, influences the performance of a company. We designed a model of the relationships between selected factors, developed hypotheses and in the empirical part, verified their validity. Management activities of core process (planning, organizing, leading, controlling) were dealt with from an interest and instrumental point of view. A population base of 3,007 small and medium-sized companies ( $\mathrm{SME}$ ) from Slovenia were included in the survey. Within the framework of statistically processing the collected data in the empirical section, we used structural equation modelling ( $\mathrm{SEM}$ ) as the central method since we checked the relations between the different variables (claims), as well as the theoretical model of the relations. The research confirmed that some interest aspects of the core process management (planning, organizing and leading) and some instrumental aspects of the core process management (controlling) influence company performance more than others.

Key words: management, company, process, business, performance, core, structural, model, Slovenia https://doi.org/10.26493/1854-4231.14.59-86

\section{Introduction and Theoretical Background}

The article discusses the activities of business process management with an emphasis on core processes as well as their impact on company performance. Business process management is a complex area, as is influenced by a number of factors, which cannot be included in the research at the same time; therefore, in this article, we will discuss the connection between these factors as a model (figure 1).

We can define the business process as a comprehensive and dynamic coordinated set of connected activities, from purchasing to the sales, which are intended for the appropriate supply of customers and enable the business performance of a company in a particular 
economic environment (Jeston and Nelis 2014, 4; Trkman et al. 2015, 125; Shulte et al. 2015, 36; Janeš, Biloslavo, and Faganel 2017, 175; Janeš, Kadoić, and Begičević Ređep 2018, 193; Bertoncel, Erenda and Meško 2018, 805; Novak and Janeš 2019, 780). Various authors have noted that managing business processes is crucial for the successful development of companies (Gošnik, Beker, and Kavčič, 2014; Kavčič, Rečnik-Krajnc, and Gošnik, 2014; Hernaus, Bosilj Vukšić, and Indihar Štemberger 2016; Kavčič and Gošnik 2016; Gošnik et al. 2016; Stojanović et al. 2017; Novak and Janeš 2019). The performance of the company, as well as its continued growth and existence, depend on the effectiveness of business processes (Indihar Štemberger et al. 2018, 425; Zelt, Schmiedel, and Vom Brocke 2018, 67). In business processes, there is always room for innovation, improvements, the involvement of employees, buyers, and suppliers - in short, the participants in a company, as only in this way are we able to develop new value and benefits for our customers. That is why within the management of a company, a systematic and comprehensive approach is necessary, especially so in the management of those processes which directly influence an increase in added value for our customers. These processes are called core processes (Kovačič and Bosilj Vukšić 2005, 31; Strnadl 2006, 13; Harmon 2007, 86, 46-47; Jeston and Nelis 2014, 4; Trkman et al. 2015, 125). This, hereinafter, represents our central research problem. We designed a model of connections between chosen factors, developed hypotheses, and in the empirical section, examined their validity (figure 1).

Reijers $(2006,389)$, as well as Potočan and Nedelko $(2015,37)$, are of the opinion that high performance ganizations these days are those that are capable of introducing changes quickly enough so that they can be leaders on the market. Hernaus, Pejić Bach, and Bosilj Vukšić $(2012,384)$ highlight the importance of achieving business goals for business performance, with a focus on the involvement of employees, external collaborators, and the effectiveness of processes. Processes, which create new products or services in a company as well as contribute to customer satisfaction and directly lead to an increase in added value, are precisely core processes (Harmon 2007, 86; Kovačič and Bosilj Vukšić 2005, 31; Uršič 2000, 65). Core processes demand careful planning, organizing, leading, and controlling, which, in one word, we call management (the management of core processes). Zelt, Schmiedel, and Vom Brocke $(2018,67)$ note that for high performance of the organizations these days, it is a prerequisite that they have an excellent management of core processes. Thennakoon et al. (2018, 478; Espino-Rodriguez and Rodriguez-Diaz 
2014 , 2) highlight the importance of the connection of the management of core processes with the objectives of a company, targetting the benefit to the customer and other participants as well as emphasising that we have to have clearly set criteria for measuring the effects of processes on company performance (Margherita 2014; Trkman, Budler, and Groznik 2015; Trkman et al. 2015; Lau et al. 2016; Rowell 2018; Arias et al. 2018).

In connection with this, it raises the question, what should the management of core processes be like to ensure the performance of a company. We have broken down each of the four activities of the management of core processes: planning, organizing, leading and controlling into instrumental and interest aspects (Tavčar 2009, 113; Stalk, Evans, and Shulman 1992, 57; Inkpen and Choudhury 1995, 313-23; De Wit and Meyers 2005, 261-66; Biloslavo 2006, 18, 328).

\section{Instrumental Aspect of the Organization}

Every organization is an instrument (a machine, device) for achieving objectives and is subordinate to the interests of the owners and founders (Stalk, Evans, and Shulman 1992, 57; Inkpen and Choudhury 1995, 313-23; De Wit and Meyers 2005, 261-66; Biloslavo 2006, 18; Tavčar 2009, 107). This is also reflected in the management of a company and the core activities of management (planning, organizing, leading, and controlling).

Planning as part of the activities of management from an instrumental perspective is founded on the short-term and one-sided focus on fulfilling the interests of the owners. Managers focus on rules, analytic decision making, and rationality (Tavčar 2009, 107; De Wit and Meyers 2005, 30-1). For planning, it is, in this case, is also characterised by focussing on existing products and processes, on highly productive processes, immediate financial results, and on financial resources before creating new core capabilities, processes, and products (Tavčar 2009, 221-22).

Organizing, as a part of the activities of management from an instrumental perspective means, above all, formalising and normalising work tasks. The division of work is founded on the needs of the organization, not on the interests of employees. Managing processes is based on controlling by establishing responsibility, with its control often made possible with the use of technology. Normative systems for achieving efficiency (high productivity) of processes prevail, and the adaptation of organizations to the market is limited (Tavčar 2009, 328-9).

From an instrumental perspective, leading, as an activity of man- 
agement, focusses on business (administration). It focusses on the monitoring of business results. Employee control is authoritarian, and management tries to circumvent employee resistance. At the forefront is the trading of existing products, not the development of new ones. The organization responds poorly to impacts from the environment (Tavčar 2009, 474-5).

From an instrumental perspective, controlling as an activity of management is called measuring. It is reflected in the quantitative measurement of processes and business performance. Employees and processes are monitored continuously, with an emphasis on costs, productivity, and maximizing short term profit rather than the long-term growth and development of the organization (Tavčar 2009, 537).

\section{Interest Aspect of an Organization}

The notion of an organization as a grouping of interests stems from a broader social conception of the purpose of an organization, as it performs better if it functions in accordance with the interests of both external (customers, suppliers, partners) and internal (employees, management, owners) participants. The interest aspect emphasises the organization as a community of interests, not just managers and owners, but also all other participants (suppliers, employees, customers, other market participants) (Stalk, Evans, and Shulman 1992, 57; Inkpen and Choudhury 1995, 313-23; Willcocks, Currie, and Jackson 1997, 617; Grover, Fiedler, and Teng 1999, 749; De Wit and Meyers 2005, 261-6; Biloslavo 2006, 18, 328; King and Burgess 2006, 59; Tavčar 2009, 107-8).

From an interest perspective, planning as an activity of management is focused on the long-term growth and on the organization performance, based upon the values of the organization as well as the participants. It focuses on acquiring new knowledge and core competencies as well as emphasising consistency with as many participants as possible in implementing goals and strategies (Tavčar 2009, 222-3; Burlton 2010, 81-97; Vom Brocke et al. 2014, 530-48; Trkman et al. 2015, 250-66).

From the perspective of interest, organizing, as an activity of management, is based on their interests in co-workers and also on the interests of other participants; they create an opportunity for creative collaboration and committed independent work of co-workers, co-operation between participants is flexible, while at the same time the organization adapts to changes in the environment (Tavčar 2009, 329-30). 
The interest aspect of leading puts an emphasis on people (employees), which is why we call it leading people, or rather employees. This aspect is characteristic of dealing with employees and other participants in the organization (e.g., suppliers, customers) as a source of creative ideas and knowledge that can ensure company performance (Ford, Ford, and D'Amelio 2008, 362; Nodeson et al. 2012, 466; Appelbaum et al. 2015, 135). Leading employees is less authoritarian, and is based on the power of knowledge, taking into account the values and needs of employees. In an organization, developed innovations in the fields of products/services and processes, have greater value than those obtained on the market. Collaboration between all market participants prevails for the common benefit and satisfaction of all. Leading employees takes into account the capabilities of employees and the circumstances; communication between participants in processes is collaborative and is based on trust and understanding (Tavčar 2009, 476-9).

We call the interest aspect of controlling, judging. Goals are the outcome of the interests of a broader range of participants, not just owners. Judgment as to the achievement of business objectives should be based on relative comparisons with competitors, through the satisfaction of participants, long-term, and is less reliable than measuring, as it is often based on the intuition of the person executing judgment (Tavčar 2009, 537 39; McCormack et al. 2009, 792; Hernaus, Pejić Bach, and Bosilj Vukšić 2012, 383; Sikdar and Payyazhi 2014, 972-4; Margherita 2014, 642; Lau et al. 2016, 233; Bisogno et al. $2016,56)$.

\section{Business Processes and Business Process Management}

In the literature, there are several different classifications of business processes. According to Strnadl $(2016,67)$ and other authors (Shulte et al. 2015, 36), a business process is a 'comprehensive, and dynamically coordinated set of activities or logically related tasks that must be performed to develop value for the customer or achieve other strategic goals of the organization.' A business process is a set of activities that generate outputs from one or more types of inputs that represent value to the customer (Sikdar and Payyazhi 2014, 971). The business process, can be defined as a 'comprehensive and dynamically coordinated set of related activities, from purchasing to the sales market, which is intended for the adequate supply of customers and enable the organization to operate in a business environment.' (Guha and Kettinger 1993, 13; Hammer 1996, 10-1; Strnadl 2006, 13; Trkman et al. 2015, 125; Gibson, Ivancevich, and Don- 
nelly 2000 and Bavec and Manzin 2012, 49). According to Kovačič et al. $(2004,58)$, it is a business process composed of logically interrelated implementation and control activities, the result of which is a product (product or service). Business processes typically do not only take place in one organizational unit. Business processes determine the quality, innovation, and productivity (efficiency) of companies (Cho and Pucik 2005, 555; Minonne and Turner 2012, 111) are a key tool for any organization which determine operating costs; they are the basis for the opportunity to increase market share and are the basis for accepting management decisions and business performance (Seethamraju 2012, 532; Potočan and Nedelko 2015, 25). The effectiveness of business processes in organizations effect the company performance and its continued growth and existence (Buh, Kovačič and Indihar Štemberger 2015, 243; Indihar Štemberger et al. 2018, 425; Zelt, Schmiedel, and Vom Brocke 2018, 67). Davenport (1993; Burlton 2010; Harmon 2003, Kovačič and Bosilj Vukšić 2005; Sinur, Odell, and Fingar 2013) defines the business process as (1) a transformation process in a business organization through which business results are generated; (2) as a comprehensive link of partial processes that ensure the overall performance of tasks; (3) a set of logically connected contractors and control procedures that result in a product or service; (4) a structured part of measurable activities for the production of a customer output (product, service); (5) linking the selected constituents of the organization to a specific collaboration to achieve goals; (6) a continuous sequence of business activities to achieve business goals.

There are various definitions of business process management in the literature today. Some definitions focus on information solutions to optimise existing processes (Davenport 1993; Smith and Fingar 2003; Chang 2006 in Potočan and Nedelko 2015, 29). Others focus on the role of business process management in improving processes and their outcomes (Slack 1996; Daft 2000; 2009; Mullins 2013; Potočan and Nedelko 2015, 30; Gobbi de Boer and Mueller 2015, 908; Bernardo et al. 2017, 155). Trkman $(2010,125)$ and Niehaves et al. $(2014,90)$ define business process management as a synthesis of different managerial practices and approaches for business optimisation (e.g., six sigma, lean business, comprehensive quality management) that enable differentiation and the competitiveness of companies. Business process management requires the development and implementation of innovative solutions in businesses and enables the differentiation and competitiveness of companies (Cho and $\mathrm{Pu}-$ cik 2005, 555; Trkman 2010, 125; Niehaves et al. 2014, 90; Pauwaert 
and Van Looy 2014, 3; Nadarajah, Latifah, and Kadir 2014, 522). Business process management requires the coordination and integration of business functions as well as motivated employees to develop new value for the customer (Strnadl 2006, 67-77). Trkman et al. $(2015,250-66)$ even discuss a new model of business process management, i.e., Customer Process Management (сРм). It follows that, in accordance with the need for process orientation, each company should plan, organize, lead, and control its business processes. This, consequently, in every company, demands, above all, mastering the management of core business processes, which is discussed later in this research.

\section{Core Processes and Core Business Process Management}

The competitiveness of every company comes from the competitiveness of processes, more precisely, core processes. The core process in a company is (or are, because there may be more) in which we create new products and services as well as contribute to customer satisfaction and directly influence the increase of added value (Kovačič and Bosilj Vukšić 2005, 31; Harmon 2007, 86). In core processes, the company changes inputs into outputs, products/services with which the company achieves its goals and objectives. In this way, in efficient companies, we recognize above all those solutions that relate to mastering core processes. Products and services are the outputs of core processes (Kovačič and Bosilj Vukšić 2005, 31 and Harmon 2007, 86). Core processes enable companies to differentiate and compete (Trkman 2010, 125; Niehaves et al. 2014, 90; Banker, Mashruwala, and Tripathy 2014, 872). In most companies, there are only a few core processes (e.g., 4 to 10) (Potočan and Nedelko 2015, 45). Core processes for a company represent capital in the form of knowledge needed to develop new ways of operating. The common characteristics of core processes coincide with the definition of the core capabilities of the company and are: (1) the core processes must have a distinct customer benefit; (2) core processes must be difficult to imitate; (3) core processes must be irreplaceable with other solutions (Rosemann and Vom Brocke 2010; Dumas et al. 2013; Sinur, Odell, and Fingar 2013; Potočan and Nedelko 2015, 46). Among the core business processes of a company are product development, service development, product manufacturing, service execution, product marketing, customer support, customer communication, order fulfillment, and production capacity development (Potočan and Nedelko 2015, 467). If the core processes are effective (productive) and innovative, this will be reflected in the performance of the company (Trkman, 
Budler and Groznik 2015, 587; Arias et al. 2018, 376; Thennakoon et al. 2018; 478; Zelt, Schmiedel, and Vom Brocke 2018, 67; Indihar Štemberger et al. 2018, 425). This applies to all businesses, regardless of size, products, or market. Based on Porter's value chain (Porter 1985), Kovačič and Bosilj Vukšić $(2005,35)$ define the following core processes: (1) the procurement process that refers to the physical flows of material required for production; (2) the process of producing products, providing services related to the transformation of input sources into output, and (3) the sales process relating to the activities associated to product distribution, downstream, sales and after-sales activities. The primary purpose of core processes must be to create new value for the customer, which is a process and requires an appropriate approach - core process management (Sinur, Odell, and Fingar 2013; Jeston and Nelis 2014; Margherita 2014; Trkman, Budler, and Groznik 2015; Potočan and Nedelko 2015; Trkman et al. 2015; Lau et al. 2016). The management of core processes involves activities: planning, organizing, leading, and controlling core processes, and for company perfomance requires that we look at them simultaneously from an instrumental and interest perspective.

\section{Core Processes and Company Performance}

According to various authors (Sinur, Odell, and Fingar 2013; Margherita 2014; Espino-Rodriguez and Rodriguez-Diaz 2014; Trkman, Budler, and Groznik 2015; Potočan and Nedelko 2015; Trkman et al. 2015; Lau et al. 2016), we can agree that for the company performance, core processes must be linked to the goals of the company, oriented towards benefit for the customer and that we must have clearly defined criteria for measuring the effects on the business. Also, in accordance with Kaplan and Norton (1996), those companies that include the aspect of core processes in their business, in addition to finance, learning, and customers, will be successful. Kaplan and Norton (1996) emphasize that we link the mission and vision of companies to the operational indicators of core processes that need to be appropriately managed from a managerial perspective. This means proper planning, organizing, leading, and controlling (Kohlbacher 2010, 135; Macedo de Morais et al. 2014, 412). Core process management involves both interest and instrumental aspects. Unsuccessful implementation of changes in the business processes is according to Trkman et al. $(2010,318)$ connected to the fact that management does not take into account instrumental and instrumental aspects of management. 


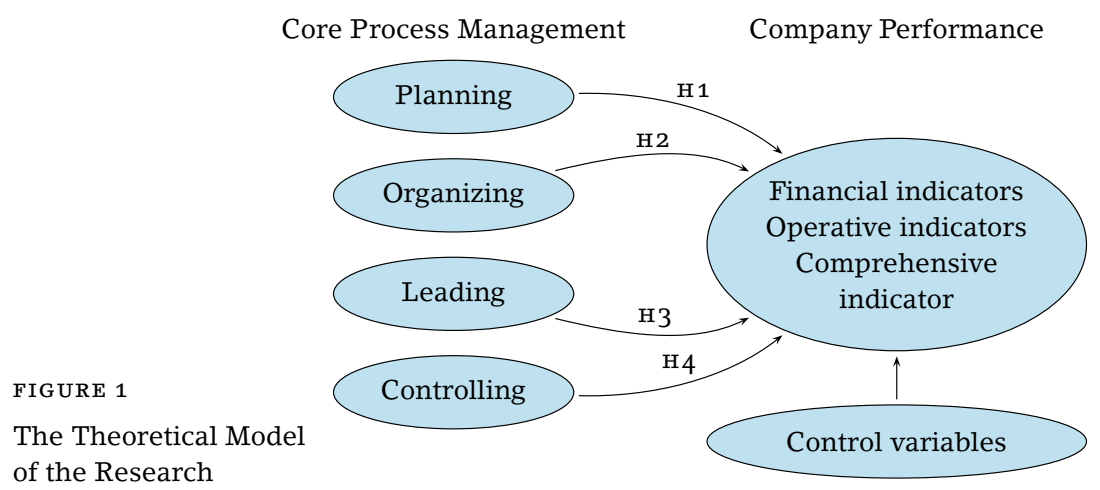

\section{Research Model and Hypothesis Development}

Based on theoretical background, we designed a theoretical model and developed four hypotheses (н1, н2, H3, H4) (figure 1).

The model is a simplification of the real situation and is an effective means of improving the efficiency and effectiveness of business (Tavčar 2009, 62). In practice, we strive that models are simple and understandable as well as clear, rich in content and that they are able to be used as extensively as possible. With the model in this research, we can perceive the connections between selected factors. In the model, we covered the factor 'Management of core processes,' in which we assumed, based on the research of the literature in the theoretical part, that it had an impact on the performance of the company. We strove to develop a model which would be comprehensive and sufficiently rich in content on the one hand, while also simple, understandable, and clear.

We considered the factor 'Management of core processes' from an interest and instrumental perspective and connected it to the performance of the company.

Based on theoretical starting points in the theoretical part, identified research gaps and in accordance with the purpose and objectives of the task, we designed a model of connections (figure 1) as well as developed four hypotheses ( $\mathrm{H} 1, \mathrm{H} 2, \mathrm{H} 3, \mathrm{H} 4)$, which were the basis for formulating the questionnaire. Based upon the literature and sources studied, the measurement of company performance was comprehensively designed with the assistance of secondary financial performance data (ROA, ROE), operating performance (EVA), and вом (business credit rating) for an extended time period. We designed this method of measurement based on the findings from the literature, as partial views of a company's performance, taking into 
account only one indicator, can provide a distorted view of a company's performance.

According to the authors' findings in the introductory chapter, the design and planning of core processes influence the performance of a company.

$\mathrm{H} 1$ The interest aspect of planning as a core process management activity has, in comparison with the instrumental aspect of planning, a more significant impact on the company performance.

$\mathrm{H} 2$ The interest aspect of organizing, as a core process management activity has, in comparison with the instrumental aspect of organizing, a more significant impact on the company performance.

$\mathrm{H} 3$ The interest aspect of leading, as a core process management activity, in comparison with the instrumental aspect of leading, has a more significant impact on the company performance.

$\mathrm{H}_{4}$ The instrumental aspect of controlling as a core process management activity, in comparison with the interest aspect of controlling, has a more significant impact on the company performance.

As part of hypothesis validation, we investigated: (1) whether there are statistically significant connections between core process management activities and the performance of a company; (2) whether the hypotheses are valid; (3) on which company performance indicators is there a statistically significant impact (ROA, ROE, EVA, воN); (4) which core process management activity has the most significant impact on the performance of a company; (5) how strong these connections are (weak, strong), and; (6) what the direction of the connections is (positive, negative).

\section{Research Methodology}

\section{DATA COLLECTING METHODOLOGY}

We used an online questionnaire to collect the data. We developed it with the assistance of reviewing the literature in the theoretical part of the research.

The questionnaire was comprised of several thematic sections. The questionnaire was made up of closed-ended questions. In terms of the nature of the questions, we included questions of fact. Respondents provided their degrees of agreement with the statements made. In order to obtain answers as different as possible, we avoided the possibility of providing 'yes' or 'no' answers. We used a six-point Likert scale to avoid responses falling into the middle of the scale (Easterby-Smith, Thorpe, and Lowe 2007, 166). 
Within the context of hypothesis testing ( 1 1, н2, н3, н4), we developed a set of statements that relate to the interest and instrumental aspects of the activities of planning, organizing, leading, and controlling core processes. The statements were developed based on a study of the literature and resources, as well as the findings in the previous chapters of the theoretical part of the research.

A Likert scale was added to each of the claims and was included in the questionnaire with descriptions as well as instructions for completion, which represents our measuring instrument for the factor 'The management of core processes.' The indicator of influence was the estimated degree of agreement by the respondents to each claim.

In our case, the performance of SMES was measured comprehensively with all the hypotheses (н1, н2, н3, н4) using secondary data (ROA, ROE, EVA, and BON). We included a time period for the last five years of business. We used the Gvin Business Database to obtain company performance data, which is a public online database for the operations of companies and provides a comprehensive insight into the position of companies on the Slovenian market (see http://www2.gvin.com).

\section{VALIDATION OF THE QUESTIONNAIRE}

The measuring instrument was developed through a review of the literature in the theoretical part of the research. The reliability of the questionnaire was verified using the Cronbach alpha $(\alpha)$ coefficient, which is intended to measure the internal consistency of the measuring instrument (Easterby-Smith, Thorpe, and Lowe 2007, 166). The questionnaire was further pre-tested in an academic setting before being sent to the companies.

\section{RESEARCH POPULATION AND SAMPLE}

The target population in our survey were SMES, which at the time of our survey on 11th of January 2017 were in the public database of business entities with headquarters in the Republic of Slovenia (AJPES database).

Sole proprietor companies were also included in the research, private limited companies, unlimited liability companies, and jointstock companies. We did not include companies in liquidation, bankruptcy, or compulsory settlement.

In the database of collected questionnaires, a sample of 163 questionnaires from companies with all completed answers remained, including the names of the said companies. Of those, 73 were small companies $(44.8 \%)$, and $90(55.2 \%)$ were medium-sized companies. 
Given the sample framework of 3,007 companies, this represents a $5.42 \%$ response rate, which is a similar response to similar research in the region (Hernaus, Pejić Bach, and Bosilj Vukšič 2012; Hernaus, Bosilj-Vukšić, and Indihar-Štemberger 2016).

\section{DATA ANALYSIS}

Within the framework of statistical processing of the collected data in the empirical part, we used as a central method the Structural Equation Modelling, in which we used correlation analysis, multiple regression analysis, and exploratory factor analysis. We used the SPSS programme (version 24.00).

We analysed the connections and performed the relationship (correlation) between variables or assertions within a factor, which we call a factor in the statistical analysis phase, is analysed and presented with the assistance of Kaiser-Maier-Olkin Test (кмо) and Bartlett's test.

Based on the results, we provided an estimate as to the validity of the connections and the influences in our theoretical model (figure 1).

\section{Results}

DEMOGRAPHIC DATA

First, we will present the information provided by the respondents about the companies where they are employed. Table 1 shows that the most significant number of companies (37.4\%) is engaged in manufacturing, while the second most frequently represented industry (10.4\%) in which businesses operate is trade and maintenance of motor vehicles.

Table 2 shows that, relative to the average number of employees in companies in 2016 , a more significant proportion $(55.2 \%$ are medium-sized enterprises, while the remaining (44.8\%) are represented by small companies (table 2).

For manufacturing companies, of which are the most common in our sample, we see that these are assembly companies, semifinished products for other companies $(80 \%)$, and are connected to a supply chain of more companies. $20 \%$ of manufacturing companies are those that produce finished products and sell them to the final consumers (buyers). This is important for the further interpretation of results in the empirical part of the research.

Table 3 shows that $35.0 \%$ of the respondents in companies perform the function of director or manager of the business function, $27.0 \%$ 
TABLE 1 The Industry in Which the Company Operates

\begin{tabular}{lrr}
\hline Industry & $f$ & $\%$ \\
\hline Agriculture and hunting, forestry and fishing & 10 & 6.1 \\
Manufacturing industry (manufacturing, etc.) & 61 & 37.4 \\
The supply of electricity, gas, and steam & 2 & 1.2 \\
The supply of water, waste management, and remediation activities & 6 & 3.7 \\
Construction business & 11 & 6.7 \\
Trade, maintenance and the maintenance of motor vehicles & 17 & 10.4 \\
Transport and storage services & 7 & 4.3 \\
Hotels and restaurants & 2 & 1.2 \\
Information and communication activities & 7 & 4.3 \\
Professional, scientific and technical activities & 9 & 5.5 \\
Other miscellaneous activities (consulting, etc.) & 2 & 1.2 \\
Education & 2 & 1.2 \\
Health and social work activities & 2 & 1.2 \\
Other & 25 & 15.3 \\
\hline Total & 163 & 100.0 \\
\hline
\end{tabular}

TABLE 2 Average Number of Employees

\begin{tabular}{lrr}
\hline Average number of employees & $f$ & $\%$ \\
\hline 10 to 49 (small companies) & 73 & 44.8 \\
50 to 249 (medium size companies) & 90 & 55.2 \\
\hline Total & 163 & 100.0 \\
\hline
\end{tabular}

are CEO's, $7.4 \%$ of the respondents perform the function of process administrators, $4.3 \%$ are the process improvement project managers, and $2.5 \%$ of respondents hold the position of Technical Directors (table 3 ).

As many as $23.9 \%$ of the respondents did not perform any of the functions they provide but are mostly employed as team members and project assistants.

TABLE 3 Current Respondent Function in the Company

\begin{tabular}{lrr}
\hline Function & $f$ & $\%$ \\
\hline General Manager & 44 & 27.0 \\
Technical Director & 4 & 2.5 \\
Director, or head of a business function (unit, department, sector) & 57 & 35.0 \\
Process Owner & 12 & 7.4 \\
Process Improvement Project Manager & 7 & 4.3 \\
Other & 39 & 23.9 \\
\hline Total & 163 & 100.0 \\
\hline
\end{tabular}


TABLE 4 Type of Core Business Process

\begin{tabular}{lrr}
\hline Type of core process & $f$ & $\%$ \\
\hline Purchase of goods and services & 13 & 8.0 \\
The development of new, improv. of existing products/services & 44 & 27.0 \\
Product manufacture & 43 & 26.4 \\
Product marketing & 24 & 14.7 \\
Executing/marketing of services & 22 & 13.5 \\
Logistics/delivery & 8 & 4.9 \\
Service/after-sales services & 6 & 3.7 \\
Other & 3 & 1.8 \\
\hline Total & 163 & 100.0 \\
\hline
\end{tabular}

\section{MANAGEMENT OF CORE PROCESSES}

In this section, we will present the results of the core set of the survey questionnaire, where we asked respondents for core process management activities that, in our relationship model (figure 1), represent one of the activities that we assumed to affect company performance.

We present the results of the type of core processes in the companies in our sample in table 4.

Table 4 shows that the majority of respondents (27.0\%) identified the development of new products and the improvement of existing products or services as the core process of the company, $26.4 \%$ of respondents identified the production of products, $14.7 \%$ identified the marketing of products as the core process of the company marketing of products, $13.5 \%$ for the implementation or marketing of services, $8.0 \%$ of respondents defined the purchase of goods or services as the core process, $4.9 \%$ of the respondents said logistics or rather delivery and 3.7\% of the respondents said services or after-sales services. $1.8 \%$ of the respondents could not place the core process in the company among the given types, but they describe their company's core process as distribution, public utilities, and call centre services.

We then focused on core business process management activities (interest and instrumental aspects).

VALIDATION OF THE THEORETICAL MODEL

According to our developed model of links (figure 1), for the factor 'Management of core processes,' which covers the fields of interest and instrumental activities, we first checked whether the individual claims within each area were sufficiently linked for the factor analysis to make sense. We also checked the internal consistency (reliabil- 
ity or repeatability) of results with similar data as measured by the Cronbach alpha parameter. We present the results of the association between interest and instrumental aspects (Pearson correlation coefficient).

For our example, we used the Phanny correlation coefficient (2009) to measure attitudes (statements) with the Pearson correlation coefficient: (from -1.0 to -0.8 very strong negative correlation; from 0.081 to -0.60 strong negative correlation; from -0.59 to -0.4 medium negative correlation; -0.39 to o weak negative correlation; o means no correlation; 0.01 to 0.39 weak positive correlation; 0.4 to 0.59 medium positive correlation; 0.6 to 0.80 strong positive correlation; from 0.81 to 1 a very strong positive correlation (Phanny 2009). Based on our method of measuring claims, we estimate that this scale is sufficiently accurate (intervals sufficiently detailed). We also separately checked the statistical significance of the association between the claims, which is denoted by an asterisk (*). This shows us the degree of connectivity. If the degree of connectivity is less than or equal to 0.05 , the relationship is statistically significant (there is an interaction). The following is the presentation of the results of the analysis of the factor 'Management of core processes,' which covers the field of interest and instrumental activities of planning, organizing, leading, and controlling the core processes.

\section{Planning as an Activity of the Management of Core Processes}

The interest and instrumental aspects of planning the core processes in our model of connections are an integral part of the factor 'Management of core processes,' which, based on the researched literature and the findings in the theoretical part, we assumed to have an influence on the dependent variable, that is, company performance (figure 1). As can be seen, the connections are positive and are of medium strength (table 5).

\section{Organizing, As a Management Activity of Core Processes}

The results show that there is a connection between the interest and instrumental aspects of organizing, perceived primarily between the first exposed aspect of planning (formalisation) and all elements of integration (table 6).

Mentioned connections are positive and weakly strong. The results show that companies have placed the most significant emphasis on networking in relation to only one exposed aspect of regulation, which is indicated by the statement 'Relationships between 


\section{Dušan Gošnik}

TABLE 5 Core Process Management Factor: The Relationship between Interest and Instrumental Aspects of Planning

\begin{tabular}{lrrrr}
\hline Interest aspect & \multicolumn{4}{c}{ Instrumental aspect } \\
\cline { 2 - 5 } & $(1)$ & $(2)$ & $(3)$ & $(4)$ \\
\hline $\begin{array}{l}\text { When designing changes to the core process, } \\
\text { we take into account the business strategy of } \\
\text { the company. }\end{array}$ & $0.413^{*}$ & 0.151 & -0.098 & 0.115 \\
\hline $\begin{array}{l}\text { When planning changes to the core process, } \\
\text { we are focused on the growth and develop- } \\
\text { ment of the company over the long run. }\end{array}$ & $0.423^{*}$ & 0.111 & -0.097 & 0.091 \\
\hline $\begin{array}{l}\text { We involve influential participants in design- } \\
\text { ing changes to the core process. }\end{array}$ & $0.294^{*}$ & 0.053 & $-0.167^{*}$ & -0.029 \\
\hline $\begin{array}{l}\text { When designing changes to the core process, } \\
\text { we are focused on customer value. }\end{array}$ & $0.319^{*}$ & 0.064 & -0.145 & -0.102 \\
\hline
\end{tabular}

NOTES Column headings are as follows: (1) when planning changes to the core process, the emphasis is on efficiency, (2) when planning changes to the core process, we emphasize immediate financial effects, (3) planning for changes to the core process takes place from top to bottom, (4) planning for changes to the core process takes place exclusively through formal meetings. * Statistically significant correlations at the feature level, smaller or equal, are indicated 0.05 (checked separately).

TABLE 6 Core Process Management Factor: Relationship between Interest and Instrumental Aspects of Organizing

\begin{tabular}{lrrrr}
\hline Interest aspect & \multicolumn{4}{c}{ Instrumental aspect } \\
\cline { 2 - 5 } & $(1)$ & $(2)$ & $(3)$ & $(4)$ \\
\hline $\begin{array}{l}\text { Changes to the core process are developed } \\
\text { through the integration of participants (sup- } \\
\text { pliers, employees, customers). }\end{array}$ & $0.370^{*}$ & 0.046 & -0.065 & $-0.252^{*}$ \\
\hline $\begin{array}{l}\text { The participants in the changes to the core } \\
\text { process are connected with the assistance of } \\
\text { the project method of work. }\end{array}$ & $0.450^{*}$ & 0.114 & 0.118 & -0.051 \\
\hline $\begin{array}{l}\text { In making changes to the core process, par- } \\
\text { ticipants are connected in a manner that } \\
\text { allows us to maximize the value of prod- }\end{array}$ & $0.348^{*}$ & 0.037 & -0.043 & $-0.155^{*}$ \\
ucts/services for the customer. & & & & \\
\hline $\begin{array}{l}\text { With participants, we are connected in a } \\
\text { manner that allows us to communicate } \\
\text { quickly and respond to changes. }\end{array}$ & $0.325^{*}$ & 0.060 & -0.055 & $-0.185^{*}$ \\
\hline
\end{tabular}

Notes Column headings are as follows: (1) the relations between participants in the changes to the core process are precisely and formally determined by regulations and rules, (2) the company gives priority to rules and procedures when handling matters related to changes to the core process, (3) in the company, there are many hierarchical levels between management and the executors of the core process at the operational level, (4) functional departments and their managers limit our ability to change the core process. * Statistically significant correlations at the feature level, smaller or equal, are indicated 0.05 (checked separately). 
TABLE 7 Core Process Management Factor: Relationship between Interest and Instrumental Aspects of Leading

\begin{tabular}{lcccc}
\hline Interest aspect & \multicolumn{4}{c}{ Instrumental aspect } \\
\cline { 2 - 5 } & $(1)$ & $(2)$ & $(3)$ & $(4)$ \\
\hline $\begin{array}{l}\text { We regularly involve process contractors in } \\
\text { changing the core process. }\end{array}$ & $-0.448^{*}$ & $-0.523^{*}$ & $-0.554^{*}$ & $-0.502^{*}$ \\
\hline $\begin{array}{l}\text { We regularly involve our customers in chang- } \\
\text { ing the core process. }\end{array}$ & $-0.249^{*}$ & $-0.265^{*}$ & $-0.242^{*}$ & $-0.297^{*}$ \\
\hline $\begin{array}{l}\text { We regularly involve our suppliers in chang- } \\
\text { ing the core process. }\end{array}$ & $-0.230^{*}$ & $-0.256^{*}$ & $-0.234^{*}$ & $-0.270^{*}$ \\
\hline $\begin{array}{l}\text { Middle management is the key to successfully } \\
\text { introducing changes to the core process. }\end{array}$ & $-0.181^{*}$ & $-0.201^{*}$ & $-0.166^{*}$ & $-0.170^{*}$ \\
\hline
\end{tabular}

NOTES Column headings are as follows: (1) contributors (process providers) do not co-decide when introducing changes to the core process, (2) when introducing changes to the core process, the authoritarian (commanding) leading of employees prevails, (3) when introducing changes to the core process, we often only follow the interests of the owner and managers in the short term, (4) the introduction of change into the core process is slow due to centralized management decision making. * Statistically significant correlations at the feature level, smaller or equal, are indicated 0.05 (checked separately).

participants in changes to the core process are precisely and formally defined by regulations and rules.' A weakly negative but statistically significant correlation can also be detected between the claim 'Changes to the core process are developed with the assistance of linking participants (suppliers, employees, customers)' and the claim 'Functional departments and their managers limit our ability to change the core process.'

\section{Leading as an Activity of the Management of Core Processes}

The results show that there is a correlation between the interest and instrumental aspects of leading, perceived primarily between the first exposed aspect of leading, which is indicated by the claim 'We regularly involve process contractors in changing the core process,' and all aspects of management. The links are medium-strong and negative. They are also statistically significant. It is also interesting that all connections are negative. This means an inverse proportional connection (table 7).

The strongest negative link emerged between the selected interest aspect of leading in the claim 'When changing the core process, we regularly involve process providers' and with two claims that characterize the instrumental aspect, the management which reads: 'In in- 
TABLE 8 Core Process Management Factor: Relationship between Interest and Instrumental Aspects of Controlling

\begin{tabular}{llllr}
\hline Interest aspect & \multicolumn{4}{c}{ Instrumental aspect } \\
\cline { 2 - 5 } & $(1)$ & $(2)$ & $(3)$ & $(4)$ \\
\hline $\begin{array}{l}\text { The success of changes to the core process is } \\
\text { judged through learning, growth, and devel- } \\
\text { opment of the company (benefits in the long }\end{array}$ & $0.475^{*}$ & $0.460^{*}$ & $0.261^{*}$ & 0.010 \\
run). & & & & \\
\hline $\begin{array}{l}\text { The success of changes to the core process is } \\
\text { judged through the benefits to the customer. }\end{array}$ & $0.363^{*}$ & $0.450^{*}$ & $0.228^{*}$ & -0.014 \\
\hline $\begin{array}{l}\text { The success of changes to the core process is } \\
\text { judged by the technological advancement of } \\
\text { the company. }\end{array}$ & $0.484^{*}$ & $-0.58^{*}$ & $0.362^{*}$ & 0.095 \\
\hline $\begin{array}{l}\text { The success of changes to the core process is } \\
\text { judged through the benefits of long-term en- } \\
\text { gagement with suppliers. }\end{array}$ & $0.285^{*}$ & $0.319^{*}$ & $0.268^{*}$ & 0.077 \\
\hline
\end{tabular}

NOTES Column headings are as follows: (1) the success of changes to the core process is measured with the assistance of clearly defined indicators, (2) the success of changes to the core process is measured with the assistance of clearly defined indicators, (3) the success of changes to the core process is measured with the assistance of clearly defined indicators, (4) the success of changes to the core process is measured with the assistance of clearly defined indicators. * Statistically significant correlations at the feature level, smaller or equal, are indicated 0.05 (checked separately).

troducing changes to the core process, the authoritarian (command) management of employees prevails' and 'In introducing changes to the core process, we often only follow the interests of the owner and managers in the short term.'

\section{Controlling as an Activity of the Management of Core Processes}

The results show that the correlation between interest and instrumental aspects of controlling planning can be detected primarily between the first and second exposed aspects of measurement and the first three aspects of judgement (table 8).

The links are medium-strong and positive, with the exception of one link (-0.014), which is not statistically significant. We observe the most influential positive associations between the second measurement claim and all judgement claims.

The strongest statistically significant correlation (0.558) was shown during the third claim judgement, which reads 'The success of changes to the core process is judged through the technological advancement of the company, and the second assertion of measurement, which reads 'The success of changes to the core process is 
TABLE 9 Summary of Hypothesis Testing Findings

\begin{tabular}{lll}
\hline Hypothesis & Confirmation & Type of influence \\
\hline H1 & Yes & $\begin{array}{l}\text { The interest aspect of planning has a positive } \\
\text { impact on ROA. }\end{array}$ \\
\hline H2 & Yes & $\begin{array}{l}\text { The interest aspect of organizing has a positive } \\
\text { effect on EVA. }\end{array}$ \\
\hline H3 & Yes & $\begin{array}{l}\text { The interest aspect of leading has a positive } \\
\text { effect on EVA and BON. }\end{array}$ \\
\hline H4 & Yes & $\begin{array}{l}\text { The instrumental aspect of controlling has a } \\
\text { positive effect on ROE. }\end{array}$ \\
\hline
\end{tabular}

measured by clearly set indicators.' The connection can be justified based on the lessons learned from the theoretical part of the thesis. Measurement is the foundation of management. What we do not measure cannot be managed. Measurement in the field of introducing change into processes refers to their effectiveness before and after the change, which is usually measured by the productivity of work, resources, or sources. This is related to investments in new technologies, the computerisation of processes, and other solutions that help us to be more efficient.

\section{Summary of Hypothesis Validation}

Our assumptions, based on theory and available literature, have been confirmed. At the beginning of the research, we set up a theoretical model (figure 1), which was our guide in the design of the questionnaire and hypothesis testing $(1,2,3,4)$. The results of the hypothesis validation are summarised in table 9 .

\section{Discussion and Implications}

Based on the established model of connections (figure 1), and the basis of the results of the performed analyses presented in the empirical part of the research, we propose the following implications for the performance of companies.

The research confirmed that some interest aspects, more than some instrumental aspects of the activities of core process management, affect the performance of a company. In the following, based on the above, we present the implications for the better performance of companies in practice.

One of the key capabilities of high performance organizations is to appropriately integrate the interest and instrumental activities of core process management into changes in core processes. 
The research confirmed that the interest aspect of planning as an activity of core process management, in comparison to the instrumental aspect of planning, has a more significant impact on the company performance. The effect is positive and affects the performance of the company via ROA. Companies should involve as many key participants as possible (suppliers, employees, customers, and others) in planning changes to core processes, while firmly abiding by the business strategy of the company.

In the research, we confirmed that the interest aspect of organizing as an activity of core process management, in comparison to the instrumental aspect of organizing, has a more significant impact on the company performance. The effect is positive and affects the performance of the company via the EVA indicator. The most significant impact on the performance of companies was observed in the field of connecting participants (suppliers, employees, customers, and others) with the method of work of the project. Companies should involve the participants, as mentioned earlier, as much as possible in projects that change core processes. Processes can always be changed (optimized, innovated) for the better with the assistance of the resources and knowledge, held by suppliers, employees, and customers.

In the research, we confirmed that the interest aspect of leading as an activity of core process management in comparison with the instrumental aspect of leading, has a more significant impact on the company performance. The effect is positive and influences the performance of the company via the EVA and BON indicators. The effect on the performance of the company (EVA) has been identified in the field of including suppliers in changes to core processes. Processes can be optimized through the knowledge, experience, core capabilities, and resources of our suppliers.

The impact on the performance of a company (воN) has been identified in the area involving middle management in changes to core processes. The introduction of change in companies should be supported by professionally trained middle management, who should act as the promoter of the process manner of thinking, on the one hand, representing the interests of the company, while at the same time, the interests of customers or users. Middle management should be the liaison between the operational level (process facilitators) and the management of the company.

On the management side of the company, there should be a commitment to find or train, motivate and retain middle management in the company by allowing them time for expert project teamwork 
in the field of process improvement and professional development.

In the research, we confirmed that the instrumental aspect of controlling as an activity of core process management has a more significant impact on the company performance. The effect is positive and affects the performance of the company via the ROE indicator. The effect on company performance (ROE) was identified in measuring the success of changes to the core process, in which it was shown that companies would be more successful if the process changes have an immediate and positive financial impact on the business. A higher ROE means a higher return on investment (e.g., into the technological modernisation of equipment in processes). From a broader perspective, the orientation for businesses is to set clear benchmarks for changes to core processes for measuring the effects of changes on business. Process changes should be based on strategic orientations as well as defined and measurable company goals.

\section{Limitations of the Research}

The limitations of the research can be divided into substantive and methodological ones. The substantive limitations come from the definition of a narrower field of research, that is, the management of core processes. Based on the identified research problem, we highlighted the following substantive limitations of the research:

- We are limited in substance to the study of core processes in companies.

- We have limited ourselves to smes in the Republic of Slovenia that existed on 11th of January 2017 in the Public Business Entity Database (AJPES) registered as going concerns.

- In the research, with respect to the legal status form, we included sole proprietors, limited liability companies, unlimited liability companies, and joint-stock companies. By not limiting the legal status, the company database would also cover various public agencies, courts, administrative units, etc. that were not the target population. We also did not include companies in bankruptcy, liquidation, or composition.

- The limitation represents the framework for the research. In terms of content, the activity of management of core processes, which covers the interest and instrumental activities of the management of core processes, was captured in the model of influence on company performance.

- Company performance was measured by selected financial indicators (ROA, ROE), the operational indicator (EVA), and the com- 
prehensive performance indicator of companies (воN). These indicators were selected based on the literature reviewed in the theoretical part of the research.

The methodological limitations refer to the research methods used in the empirical part of the research:

- The limitation of the survey is the measuring instrument. We used a quantitative method of data collection with the assistance of a closed-ended online questionnaire.

- A limitation is the sample of 163 companies, from which we received duly completed survey questionnaires.

- The respondents completed the survey voluntarily. They voluntarily entrusted us with their company's name, which was a prerequisite for successfully obtaining data from publicly available company performance databases (ROA, ROE, EVA, BON).

- The anonymity of the survey was ensured by not disclosing the names of the respondents, company names, or trade secrets. The data were processed in aggregate (together in average values) and in interpretation are not related to any individual company or respondent.

\section{Future Studies}

Based on the set-theoretical model and the design of the empirical part of the research as well as the results, we see opportunities for further research in the following direction:

1. Conducting periodic surveys for the purpose of comparative studies for the same population of companies by gathering data on core processes and performance anew for a later period of time. We could also re-compile company performance data and investigate how the state, in the area of core process management, with a time lag, influences the performance of companies. This makes sense as changes in the areas of processes of company performance are only reflected over time.

2. The survey could be carried out separately for manufacturing companies and separately for service companies.

3. We could also include other performance-impacting factors into the model that we have not covered so far (e.g., business ownership, product type/service, strategy towards competitors, and others), as well as research their impact on the performance of companies. 
4. Comparable studies could be carried out in similar transition economies, such as Slovenia, for example, Croatia, Serbia, Slovakia, Hungary, and the Czech Republic. For all these larger economies listed, the sample size could significantly exceed the sample in our study. This would add weight and provide a greater generalization of the research findings.

5. All of the above could be repeated in large companies, which are not currently included in this survey. In them, we have to deal with a greater division of work, different organization, deeper organizational structures, stronger positions on the market (e.g., against suppliers, customers), and we estimate that the survey would show mixed results.

We believe that the proposals for further research are entirely achievable. The designed model is universal. This means that it is not bound to a specific industry or one type of company; it covers comprehensive data on the management of core processes, includes opinions and facts, measures the performance of companies: financially, operationally, and comprehensively and covers a time dimension (multi-year periods). The designed model could be used in different economies and industries. Findings from repeated research can also help us in the future to improve company performance.

\section{References}

Appelbaum, S. H., M. D. Cesar, O. O. MacDonald, and N. Q. Thai-Son. 2015. 'Organizational Outcomes of Leadership Style and Resistance to Change (Part Two).' Industrial and Commercial Training 47 (3): 135-44.

Arias, M., S. Rodrigo, M. R. Marques, J. Munoz-Gama, and M. Sepúlveda. 2018. 'Human Resource Allocation in Business Process Management and Process Mining: A Systematic Mapping Study.' Management Decision 56 (2): 376-405.

Banker, R. B., R. Mashruwala, and A. Tripathy. 2014. 'Does Differentiation Strategy Lead to More Sustainable Financial Performance than a Cost Leadership Strategy?' Management Decision 52 (5): 872-96.

Bavec, C., and M. Manzin. 2012. Strukturni vidiki organiziranosti. Koper: Fakulteta za management.

Bernardo, R., S. Vasconcelos, G. Ribeiro, and S. I. D. de Pádua. 2017. 'The в $\mathrm{M}$ Lifecycle: How to Incorporate a View External to the Organization through Dynamic Capability.' Business Process Management Journal 23 (1): 155-75.

Bertoncel, T., I. Erenda, and M. Meško. 2018. 'Managerial Early Warning System as Best Practice for Project Selection at a Smart Factory.' Amfiteatru Economic 20 (49): 805-19. 
Biloslavo, R. 2006. Strateški management in management spreminjanja. Koper: Fakulteta za management.

Bisogno, S., A. Calabrese, M. Gastaldi, and N. L. Ghiron. 2016. 'Combining Modelling and Simulation Approaches: How to Measure Performance of Business Processes.' Business Process Management Journal 22 (1): 56-74.

Buh, B., A. Kovačič and M. Indihar Štemberger. 2015. 'Critical Success Factors for Different Stages of Business Process Management Adoption: A Case Study.' Economic Research 28 (1): 243-58.

Burlton, R. T. 2010. Delivering Business Strategy through Process Management: Handbook on Business Process Management 2. Heidelberg: Springer.

Chang, J. F. 2006. Business Process Management Systems: Strategy and Implementation. Boca Ration, FL: Taylor \& Francis.

Cho, H. J., and V. Pucik. 2005. 'Relationship between Innovativeness, Quality, Growth, Profitability, and Market Value.' Strategic Management Journal 17 (3): 555-75.

Daft, R. L. 2000. Management. 5th ed. Orlando, FL: Dryden.

- 2009. Organization Theory and Design. Cincinnati, он: SouthWestern.

Davenport, T. H. 1993. Process Innovation: Re-Engineering Work through Information Technology. Boston, MA: Harvard Business Review Press.

De Wit, B., and R. Meyers. 2005. Strategy Synthesis. London: Thomson Learning.

Dumas, M., M. La Rosa, J. Mendling, and H. A. Reijers. 2013. Fundamentals of Business Process Management. Berlin: Springer.

Easterby-Smith, M., R. Thorpe, and A. Lowe. 2007. Raziskovanje v managementu. Koper: Fakulteta za management.

Espino-Rodriguez, F. T., and M. Rodríguez-Diaz. 2014. 'Determining the Core Activities in the Order Fulfillment Process: An Empirical Application.' Business Process Management Journal 20 (1): 2-24.

Ford, J. D., L. W. Ford, and A. D'Amelio. 2008. 'Resistance to Change: The Rest of the Story.' Academy of Management Review 33 (2): 362-77.

Gibson, J. L., J. M. Ivancevich, and J. H. Donnely. 2000. Organizations: Behavior, Structure, Processes. Burr Ridge, IL: Irwin.

Gobbi de Boer, F., and C. J. Mueller. 2015. 'Assessment Model for Organizational Business Process Maturity with a Focus on B nance Practices.' Business Process Management Journal 21 (4): 90827.

Gošnik, D., I. Beker, and K. Kavčič. 2014. 'Lean Six Sigma in Slovenian and Serbian Manufacturing Companies.' International Journal of Industrial Engineering and Management 5 (3): 123-30.

Gošnik, D., I. Beker, J. Suklan, and K. Kavčič. 2016. 'Management Model for Successful Business Processes: The Case of Transition Coun- 
tries.' International Journal of Industrial Engineering and Management 7 (2): 75-83.

Grover, V., K. D. Fiedler, and J. T. C. Teng. 1999. 'The Role of Organizational and Information Technology Antcedents in Reengineering Initiation Behavior.' Decision Sciences 30 (3): 749-82.

Guha, S., and W. J. Kettinger. 1993. 'Business Process Reengineering.' Information Systems Management 10 (3): 13-22.

Hammer, M. 1996. Beyond Reengineering: How the Process-Centred Organization Is Changing Our Work and Lives. London: Harper Collins.

Harmon, P. 2003. Business Process Change: A Manager's Guide to Improving, Redesigning, and Automating Processes. Amsterdam: Kaufmann.

- 2007. Business Process Change: A Guide for Business and врм Managers and Six Sigma Professionals. Burlington: Elsevier Morgan Kaufman Publishers.

Hernaus, T., V. Bosilj Vuksic, and M. Indihar Štemberger. 2016. 'How To Go from Strategy to Results? Institutionalising в м мovernance within Organisations.' Business Process Management Journal 22 (1): 173-95.

Hernaus, T., M. Pejić Bach, and V. Bosilj Vukšić. 2012. 'Influence of Strategic Approach to в $\mathrm{M}$ on Financial and Non-Financial Performance.' Baltic Journal of Management 7 (4): 376-96.

Indihar Štemberger, M., B. Buh, L. Glavan-Milanovič, and J. Mendling. 2018. 'Propositions on the Interaction of Organizational Culture with Other Factors in the Context of врм Adoption.' Business Process Management Journal 24 (2): 425-45.

Inkpen, A., and N. Choudhury. 1995. 'The Seeking of Strategy Where Is Not: Towards the Theory of Strategic Absence.' Strategic Management Journal 16 (4): 313-23.

Janeš, A., R. Biloslavo, and A. Faganel. 2017. 'Sustainable Business Model: Case Study of Fonda.si.' Annales: Series Historia et Sociologia 27 (1): 175-90.

Janeš, A., N. Kadoić, and N. Begičević Ređep. 2018. 'Differences in Prioritization of the BSc's Strategic Goals Using AHP and ANP Methods.' Journal of Information and Organizational Sciences 42 (2): 193-217.

Jeston, J., and J. Nelis. 2014. Business Process Management: Practical Guide to Successful Implementation. London: Routledge.

Kaplan, R. S., and D. P. Norton. 1996. The Balanced Score Card: Translating Strategy into Action. Boston, MA: Harvard Business School Press.

Kavčič, K. and D. Gošnik. 2016. 'Lean Six Sigma Education in Manufacturing Companies: The Case of Transitioning Markets.' Kybernetes 45 (9): 1421-36.

Kavčič, K., I. Rečnik-Krajnc, and D. Gošnik. 2014. 'Vloga in pomen popisa procesov pri izboljšanju izvajanja dejavnosti menedžmenta.' Projektna mreža Slovenije 17 (2-3): 14-22. 
King, S. F., and T. F. Burgess. 2006. 'Beyond Critical Success Factors: A Dynamic Model of Enterprise System Innovation.' International Journal of Information Management 26 (1): 59-69.

Kohlbacher, M. 2010. 'The Effects of Process Orientation: A Literature Review.' Business Process Management Journal 16 (1): 135-52.

Kovačič, A., in V. Bosilj Vukšić. 2005. Management poslovnih procesov: prenova in informatizacija poslovanja s praktičnimi primeri. Ljubljana: Gv založba.

Kovačič, A., J. Jaklič, M. Indihar Štemberger, and A. Groznik. 2004. Prenova in informatizacija poslovanja. Ljubljana: Ekonomska fakulteta.

Lau, H., D. Nakandala, P. Samaranayake, and P. K. Shum. 2016. 'врм for Supporting Customer Relationship and Profit Decision.' Business Process Management Journal 22 (1): 231-55.

Macedo de Morais, R., S. Kazan, S. I. D. de Paadua, and A. Costa Lucirton. 2014. 'An Analysis of в м м Lifecycles: From a Literature Review to a Framework Proposal.' Business Process Management Journal 20 (3): 412-32.

Margherita, A. 2014. 'Business Process Management System and Activities.' Business Process Management Journal 20 (5): 642-62.

McCormack, K., J. Willems, J. Van den Bergh, D. Deschoolmeester, P. Willaert, M. Indihar Stemberger, R. Škrinjar, P. Trkman, M. Bronzo Ladeira, M. P. Valadares De Oliveira, V. Bosilj Vuksić, and N. Vlahović. 2009. 'A Global Investigation of Key Turning Points in Business Process Maturity.' Business Process Management Journal 15 (5): 792-815.

Minonne, C., and G. Turner. 2012. 'Business Process Management: Are You Ready for the Future?' Knowledge and Process Management 19 (3): 111-20.

Mullins, L. J. 2013. Management and Organisational Behaviour. London: F T Publishing International.

Nadarajah, D., S. Latifah, and S. A. Kadir. 2014. 'A Review of the Importance of Business Process Management in Achieving Sustainable Competitive Advantage.' The тQм Journal 26 (5): 522-31.

Niehaves, B., J. Poeppelbuss, R. Plattfaut, and J. Becker. 2014. 'Врм Саpability Development: A Matter of Contingencies.' Business Process Management Journal 20 (1): 90-106.

Nodeson, S., B. Prashant, R. Gopalan, and C. Ramendran. 2012. 'Leadership Role in Handling Employee's Resistance: Implementation of Innovation.' Interdisciplinary Journal of Contemporary Research in Business 4 (1): 466-77.

Novak, R., and A. Janeš. 2019. 'Business Process Orientation in the Slovenian Power Supply.' Business Process Management Journal 25 (4): $780-98$.

Pauwaert, T., and A. Van Looy. 2014. 'A Literature Study on the State-ofthe-art of Contingency Research in Business Process Management.' 
In Lecture Notes in Computer Science, edited by R. Meersman, H. Panetto, A. Mishra, R. Valencia-Garcia, A. L. Soares, I. Ciuciu, and F. Ferri, 8842:3-7. Berlin: Springer.

Phanny, I. 2009. 'Guideline for Interpreting Correlation Coefficient.' https://www.slideshare.net/phannithrupp/guideline-for -interpreting-correlation-Coefficient

Porter, M. E. 1985. Competitive Advantage. New York: The Free Press.

Potočan, V., and Z. Nedelko. 2015. Poslovni procesi v organizacijah. Maribor: Self-published.

Reijers, H. 2006. 'Implementing врм Systems: The Role of Process Orientation.' Business Process Management Journal 12 (4): 389-409.

Rosemann, M., and J. Vom Brocke. 2010. The Six Core Elements of Business Process Management: Handbook on Business Process Management. Berlin: Springer.

Rowell, J. 2018. 'Do Organisations Have a Mission for Mapping Processes?' Business Process Management Journal 24 (1): 2-22.

Seethamraju, R. 2012. 'Business Process Management: A Missing Link in Business Education.' Business Process Management Journal 18 (3): $532-47$.

Shulte, S., C. Janiesch, S. Venugopal, and I. Weber. 2015. 'Elastic Business Process Management: State of the Art and Open Challenges for в $\mathrm{M}$ in the Cloud.' Future Generation Computer Systems 46:36-50.

Sikdar, A., and J. Payyazhi. 2014. 'A Process Model of Managing Organizational Change During Business Process Redesign.' Business Process Management Journal 20 (6): 971-98.

Sinur, J., J. Odell, and P. Fingar. 2013. Business Process Management: The Next Wave. Tampa, FL: Meghan-Kiffer.

Slack, N. 1996. The Blackwell Encyclopedic Dictionary of Operations Management. Cambridge: Blackwell Publishers.

Stalk, G., P. Evans and L. E. Shulman. 1992. 'Competing on Capabilities: The New Rules of Corporate Strategy.' Harward Business Review 70 (2): 57-69.

Stojanović, D., I. Tomašević, D. Slović, D. Gošnik, J. Suklan, and K. Kavčič. 2017. 'ВРм in Transition Economies: Joint Empirical Experience of Slovenia and Serbia.' Ekonomska istraživanja 30 (1): 1237-56.

Strnadl, C. F. 2006. 'Aligning Business and гт: The Process-Driven Architecture Model.' Information Systems Management 23 (4): 67-77.

Tavčar, M. I. 2009. Management in organizacija: sinteza konceptov organizacije kot instrumenta in kot skupnosti interesov. Koper: Fakulteta za management.

Thennakoon, D., W. Bandara, E. French, and P. Mathiesen. 2018. 'What Do We Know about Business Process Management Training? Current Status of Related Research and a Way Forward.' Business Process Management Journal 24 (2): 478-500. 
Trkman, P. 2010. 'The Critical Success Factors of Business Process Management.' International Journal of Information Management 30 (2): $125-34$.

Trkman, P., M. Budler, and A. Groznik. 2015. 'A Business Model Approach to Supply Chain Management.' Supply Chain Management 20 (6): 587-602.

Trkman, P., W. Mertens, S. Viaene, and P. Gemmel. 2015. 'From Business Process Management to Customer Process Management.' Business Process Management Journal 21 (2): 250-66.

Uršič, D. 200o. 'Organizacijske spremembe v podjetjih v Sloveniji.' Organizacija 33 (7): 475-8.

Vom Brocke, J., T. Schmiedel, J. Recker, P. Trkman, W. Mertens, in S. Viaene. 2014. 'Ten Principles of Good Business Process Management.' Business Process Management Journal 20 (4): 530-48.

Willcocks, L. P., W. Currie, and S. Jackson. 1997. 'In Pursuit of the ReEngineering Agenda.' Public Administration 75 (4): 617-49.

Zelt, S., T. Schmiedel, and J. Vom Brocke. 2018. 'Understanding the Nature Of Processes: An Information-Processing Perspective.' Business Process Management Journal 24 (1): 67-88.

This paper is published under the terms of the Attribution-

NonCommercial-NoDerivatives 4.0 International (CC BY-NC-ND 4.0)

License (http://creativecommons.org/licenses/by-nc-nd/4.o/). 